DOI https://doi.org/10.18551/rjoas.2020-12.03

\title{
DETERMINANT ANALYSIS IN ACCOUNTING CONSERVATISM
}

\author{
Wijayanti Inung, Yustisia Natali, Abdurrahman Farid \\ Perbanas Institute, Indonesia \\ *E-mail: inung@perbanas.id
}

\begin{abstract}
This study aims to analyze the effect of managerial ownership structure, growth opportunities, leverage, and financial distress on accounting conservatism in manufacturing companies, especially the various industrial sectors and consumer goods in the Indonesia Stock Exchange for the period 2015-2017. Sampling used purposive sampling to obtain 21 companies. The data analysis technique uses panel data that is processed with Eviews 10. Based on partial tests, variables that have a significant positive effect on accounting conservatism are leverage and financial distress. Conversely, managerial ownership structure and growth opportunities have no significant effect on accounting conservatism. Then, the $F$ test results show there is a simultaneous influence between the variables of managerial ownership structure, growth opportunities, leverage and financial distress on accounting conservatism. The test results for the coefficient of determination of 82.77 percent, which means the ability of the independent variable in explaining accounting conservatism in this study amounted to 82.77 percent, while the remaining 17.23 percent was influenced by other variables not used in this study.
\end{abstract}

\section{KEY WORDS}

Accounting conservatism, financial distress, growth opportunities, leverage, managerial ownership structure.

Large or small ownership structure in a company can affect the policies to be run by a company, whether the company will use the conservatism method or not. There are several factors in determining a manager's decision to use conservative methods or not. If managerial ownership is higher than external parties, the company will tend to use the method of accounting conservatism. In addition to ownership structure, growth opportunities also affect conservatism (Nasir et al, 2014).

Sari et al. (2014) state that growth opportunity is a company's ability to increase size, which can be proxied by an increase in assets, equity, profits and sales. According to Saputra et al (2016), growth opportunity is a company opportunity to make profitable investments for the company. If a company has a high level of growth opportunity, it will require substantial funds, because to finance growth in the future. In addition, financial distress also influences the decision making whether the company will carry out accounting conservatism.

Financial distress (level of financial difficulties) can be interpreted as an early symptom of bankruptcy due to a decline in financial conditions experienced by a company. Financial distress can affect the level of conservatism, because a company experiencing a level of financial difficulty will encourage companies to carry out accounting conservatism in their financial statements (Dewi \& Suryanawa, 2014).

Leverage is a ratio (comparison) that shows how much debt or capital is in financing company assets. According to Brigham \& Daves (2011), the use of debt at a certain level will be able to reduce the cost of corporate capital because the cost of debt is a reduction of corporate taxes, and can increase stock prices, which in turn this will benefit management and investors. Usually the higher the level of leverage, the more likely the company will violate the credit agreement, so the company will try to report higher profits now that can be done by reducing existing costs.

Research on accounting conservatism has been done a lot, but the results are still not consistent, so researchers are interested in doing further similar research. The specific 
purpose of this study is to analyze the effect of managerial ownership structure, growth opportunities, leverage and financial distress on accounting conservatism either partially or simultaneously. The object of the research is manufacturing companies listed on the Indonesia Stock Exchange for the period of 2015 - 2017, specifically the various industrial sectors and the consumer goods industry.

\section{LITERATURE REVIEW}

Accounting conservatism is presenting understated assets and income in financial statements, and presenting overstated liabilities and expenses in financial statements. In this concept, the expenses must be immediately recognized first compared to income, so that net income becomes low. The application of this principle results in the choice of accounting methods that report lower profits or assets and report higher debt (Wahyuni \& Muchlis, 2016).

Managerial ownership structure is the company's stock structure owned by managers who act as well as the company's shareholders (Christiawan and Tarigan, 2007). Ownership structure can be defined as a comparison between the number of shares owned by an insider (management) and the number of shares owned by an investor. The ownership structure can also be said as a separation between company owners and company managers (Sudana, 2011). Managerial ownership can also be said as a comparison between managerial share ownership with the number of shares outstanding. Shareholders and managers are each interested in maximizing their goals (Soesetio, 2008).

According to Syafi'i (2011), growth opportunities can indicate a company's ability to develop in the future by utilizing investment opportunities. The use of investment opportunities and their utilization can be done if a company has adequate human, financial and technological resources (Fatmawati, 2011). If the company will invest from the funds it has, then this will be a cost.

Seftiani and Handayani (2011) explain that growth opportunities illustrate how investors value the company, so investors are willing to invest in the company. Companies that have a higher market value compared to their real assets (assets in place), it can be said that the company is experiencing growth. Growth opportunities can be measured using market to book value equity.

Leverage is a ratio used to measure a company's ability to pay long-term obligations. This ratio is the same as the solvency ratio, which is the ratio to find out the company's ability to pay its obligations if the company is liquidated (Saputra, 2016).

Financial distress is a company's financial condition that has declined, but before the company went bankrupt or liquidated (Platt \& Platt, 2002 and Sulastri \& Anna, 2018). Companies that cannot afford financial obligations that are past due can also be called financial distress (Ramadhani and Lukviarman, 2009). Bankruptcy is one of the problems faced by companies, but it can be avoided by predicting the causes that can lead to bankruptcy (Sulastri \& Anna, 2018). In general, companies that experience financial distress can be caused by economic problems, decreased performance and poor management (Fachrudin, 2008). According to Harahap (2018), the calculation of financial distress can be done with Altman's Bankruptcy Prediction Mode (Z-Score).

Research on accounting conservatism has been carried out by using various variables and producing various conclusions. The results of Dewi and Suryanawa's research (2014) state that managerial ownership structure and leverage have a significant positive effect on accounting conservatism, while financial distress has a significant negative effect on accounting conservatism. The results of a study conducted by Septian and Anna (2014) also concluded that the variables of managerial ownership, company size, debt covenants and growth opportunities simultaneously had a significant effect on accounting conservatism. Partially managerial ownership and firm size significantly influence accounting conservatism, while debt covenants and growth opportunities do not significantly influence accounting conservatism. 
Referring to the research conducted by Noviantari and Ratnadi (2015) concluded that financial distress and leverage negatively affect accounting conservatism, but company size has a positive effect on accounting conservatism. Furthermore, Saputra's research (2016) concluded that leverage had a significant positive effect on accounting conservatism, while the level of financial difficulties did not significantly influence accounting conservatism. Dewi \& Suryanawa (2014) found that managerial ownership structure and leverage had a significant positive effect on accounting conservatism, while financial distress had a significant negative effect on accounting conservatism.

Hypothesis:

- $\mathrm{H}_{1}$ : Managerial ownership structure influences conservatism accounting;

- $\mathrm{H}_{2}$ : Growth opportunities affect accounting conservatism;

- $\mathrm{H}_{3}$ : Leverage affects accounting conservatism;

- $\mathrm{H}_{4}$ : Financial distress influences accounting conservatism;

- $\mathrm{H}_{5}$ : Managerial ownership structure, growth opportunities, leverage, and financial distress simultaneously influences accounting conservatism.

\section{METHODS OF RESEARCH}

The variables used in this study, namely the dependent variable Accounting Conservatism $(Y)$. While the independent variables $(X)$ in this study are Managerial Ownership Structure $\left(X_{1}\right)$, Growth Opportunities $\left(X_{2}\right)$, Leverage $\left(X_{3}\right)$ and Financial Distress $\left(\mathrm{X}_{4}\right)$.

Table 1 - Name of the Sample Company

\begin{tabular}{|l|l|l|}
\hline \multicolumn{1}{|c|}{ No } & \multicolumn{1}{c|}{ Code } & \\
\hline 1 & AMIN & PT Atmindo Tbk \\
\hline 2 & ASII & PT Astra International Tbk \\
\hline 3 & GJTL & PT Gajah Tunggal Tbk \\
\hline 4 & INDS & PT Indospring Tbk \\
\hline 5 & NIPS & PT Nipress Tbk \\
\hline 6 & PRAS & PT Prima Alloy Steel Universal Tbk \\
\hline 7 & SMSM & PT Selamat Sempurna Tbk \\
\hline 8 & HDTX & PT Panasia Indo Resources Tbk \\
\hline 9 & ALTO & PT Tri Banyan Tirta Tbk \\
\hline 10 & INDF & PT Indofood Sukses Makmur Tbk \\
\hline 11 & SKBM & PT Sekar Bumi Tbk \\
\hline 12 & SKLT & PT Sekar Laut Tbk \\
\hline 13 & STTP & PT Siantar Top Tbk \\
\hline 14 & ULTJ & PT Ultrajaya Milk Industry \\
\hline 15 & WIIM & PT Wismilak Inti Makmur Tbk \\
\hline 16 & KAEF & PT Kimia Farma Tbk \\
\hline 17 & KINO & PT Kino Indonesia Tbk \\
\hline 18 & MBTO & PT Martina Berto Tbk \\
\hline 19 & TCID & PT Mandom Indonesia Tbk \\
\hline 20 & KICI & PT Kedaung Indah Can Tbk \\
\hline 21 & LMPI & PT Langgeng Makmur Industri Tbk \\
\hline
\end{tabular}

Source: Researcher (2019).

The population used is all manufacturing companies, especially various industrial sectors and consumer goods industries that are listed on the Indonesia Stock Exchange (BEI) in 2015 - 2017. The sampling is done by using the non-probability sampling method with purposive sampling technique. The criteria to be used are:

- Manufacturing companies in various industry sectors and registered consumer industries and have published audited financial statements for the period 2015 2017;

- Companies whose financial statements end on December 31 during the period 2015 -2017 ; 
- Companies that have a managerial ownership structure in the period $2015-2017$;

- Companies that were not delisted in the period 2015 - 2017;

- In preparing the company's financial statements using Rupiah;

- Complete financial statements of the Company in accordance with the requirements for data calculation in this study.

Data analysis method used is panel data regression method which is processed with Eviews 10. There are three models that can be used to estimate panel data regression including Ordinary Least Square (OLS) or Common Effect, Fixed Effect and Random Effects. Then to find out the right model, Chow test, Hausman test and Lagrange Multiplier (LM) test were performed.

In this study the classic assumption tests conducted include, normality test, multicollinearity test, and heteroscedasticity test. This test is done before testing the research hypothesis.

Correlation analysis is a useful analysis to find out whether there is a strong relationship or vice versa between the independent variables with the dependent variable. The test used is a partial test ( $t$ test), simultaneous test ( $F$ test) and the coefficient of determination test (Adjusted $\mathrm{R}^{2}$ ).

\section{DISCUSSION OF RESULTS}

Based on the classic assumption test that has been done, the regression model has fulfilled the BLUE (Best, Linear, Unlock Estimator) criteria. The test results include:

1) Test for normality, normally distributed because the probability value is above 0.05 which is equal to 0.623977 ;

2) Multicollinearity test, between independent variables, the value is below 0.9 , so there is no problem for multicollinearity;

3) Heteroscedasticity test, the probability value $>0.05$, it can be concluded that there is no heteroscedasticity.

After testing the panel data regression model to select the panel data regression model that will be used through the Chow test, the Hausman test and the Lagrange Multiplier test, the results are obtained that the panel data regression model suitable for this study is the Common Effect panel data regression model. Following are the outputs that have been carried out in this study through Eviews 10 software.

Regression Equation:

$$
Y=-0.069378-0.012568 X_{1}+0.000418 X_{2}+0.016549 X_{3}+0.012323 X_{4}
$$

Partial Test Results:

1. The probability value generated by the managerial ownership variable $\left(X_{1}\right)$ is 0.7622 $>(0.05)$, indicating that managerial ownership $\left(X_{1}\right)$ has no significant effect on conservatism (Y).

2. The probability value generated by growth opportunities $\left(X_{2}\right)$ is $0.9347>(0.05)$, indicating that growth opportunities $\left(\mathrm{X}_{2}\right)$ has no significant effect on conservatism $(\mathrm{Y})$.

3. The probability value generated by leverage $\left(X_{3}\right)$ is $0.0000<(0.05)$, indicating that leverage $\left(X_{3}\right)$ has a significant positive effect on conservatism $(Y)$.

4. The probability value generated by financial distress $\left(X_{4}\right)$ is $0.0000<(0.05)$, which shows that financial distress $\left(\mathrm{X}_{4}\right)$ significant positive effect on conservatism $(\mathrm{Y})$.

Since the probability value (F-statistic) is below 0.05 , it can be concluded that managerial ownership, growth opportunities, leverage and financial distress simultaneously influence accounting conservatism. This is because the probability (F-statistic) has a value of 0.000000 (table 2).

Based on the test results in table 2, managerial ownership has no significant effect on conservatism. It can be seen that partially the t test obtained a probability value of $0.7622>\alpha$ (0.05), so that $\mathrm{H}_{1}$ is rejected. 
No influence of managerial ownership structure variables on conservatism due to management ownership tends to be low makes the company prioritize the profits to be obtained and presented in the financial statements. This is because the company does not have a reserve fund to increase investment. Company managers make optimistic financial reports and management believes that for a certain period of time the company's business scope can be controlled.

Table 2 - Panel Data Regression Common Effect

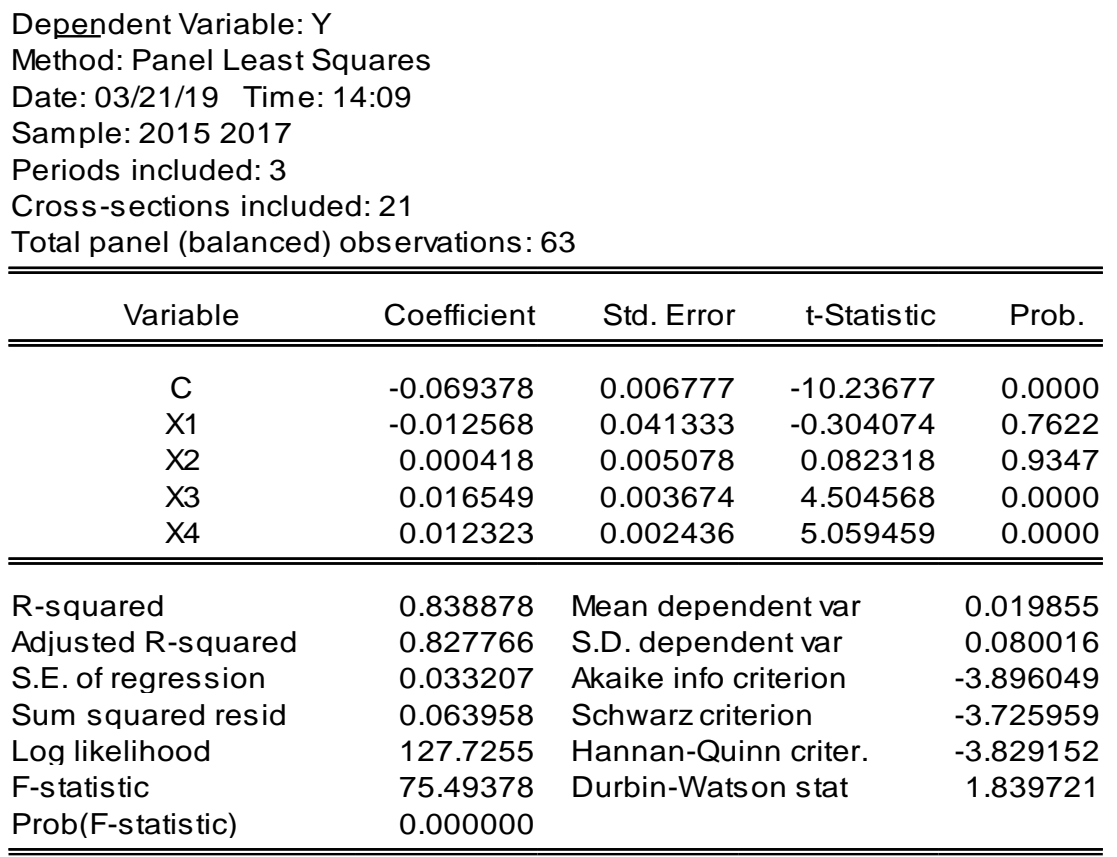

Source: Data Processing Result (2019).

These results are in line with several studies that have been conducted, including Ramadona et al (2016), Wulandari (2014) and Sinambela \& Almilia, (2018). They argue that managerial ownership is not much and because managerial ownership is not considered important by a management, so the company does not apply conservatism. As a result, all sales are recognized in the current year so that management gets a bonus for their achievement during one accounting period. But the results are different from the research conducted by Fatmariani (2013), which states that managerial ownership structure has a significant negative effect on accounting conservatism.

The company's ability to develop in the future by utilizing investment opportunities, can be said as growth opportunities. This investment opportunity can be made if the company has sufficient financial, technical, and human resources so that it can proceed as expected.

Based on the test results in table 2, growth opportunities has no significant effect on conservatism. This can be seen by the partial test or t test which obtained a probability value of $0.9347>\alpha(0.05)$, so $\mathrm{H}_{2}$ is rejected. The results of this study are supported by Susanto \& Ramadhani (2016) which states that not all company managers apply the principle of accounting conservatism by minimizing profits, which will be used to meet their investment needs. Growth opportunities require funds that mostly come from external parties so the company does not apply conservatism.

This is also in line with research conducted by Septian \& Anna (2014) which states that growth opportunities do not significantly influence the application of accounting conservatism. Companies that implement growth opportunities show that the company is developing, by increasing the value of the company. If the company raises profits, the company's financial statements do not contain conservative principles, this is certainly done to attract the attention of investors. 
Leverage is used to measure how much the company's assets are financed by shortterm debt and long-term debt. Debt levels can be identified through leverage ratios. Based on the test results in table 2 , leverage significantly influences conservatism. This result can be seen partially or $t$ test which obtained the probability value $0.0000<\alpha(0.05)$ or $\mathrm{H}_{3}$ is received.

The greater the level of leverage then the creditor has the right to know and supervise how the company operates and its accounting system. The creditor has an interest in the security of funds that are expected to benefit his side. While the company will be careful because the high level of leverage will threaten the company's sustainability. In general, companies with high leverage have a high probability of breaking credit agreements, thus companies will report higher or conservative current year earnings.

This is supported by Sulastri \& Anna (2018), Ramadona (2016), and Quljanah et al (2017) which states that leverage significantly influences the application of accounting conservatism. According to Dewi \& Suryanawa (2014), significant results between leverage and conservatism can minimize the asymmetry of information between creditors and management so that management cannot report earnings values in an overstated manner.

Financial distress is a condition that shows the stage of decline in a company's financial condition. Financial distress is characterized by the company's inability to pay shortterm or long-term debt.

Based on the test results in table 2 obtained data that states that financial distress has a significant positive effect on conservatism. It can be seen that partially the test obtained a probability value of $0.0000>\alpha(0.05)$ so that $\mathrm{H}_{4}$ is accepted. This conclusion is in line with research conducted by Risdiyani \& Kusmuriyanto (2015).

When using the signaling theory, the company will choose a conservative accounting method, so that management will recognize the recognition of low profits. And management will convey this information honestly and carefully to avoid conflicts between management and shareholders. Management thinks this is to minimize the uncertainty of the business world in the future.

This finding also supports several studies that have been conducted, including Zuhriyah (2017) and Sulastri \& Anna (2018) who concluded that financial distress has a positive effect on accounting conservatism. That is, if the company experiences financial distress, the company will apply the principle of accounting conservatism that can minimize the possibility of bad or uncertainty in the future. If a company is experiencing financial difficulties, the company tends to use the principle of conservatism so that management prefers conservative methods that are expected to reduce the excessive optimistic nature of management in predicting that the company will be better in the future than it is today.

Based on the test in table 2, the results obtained indicate that the effect of managerial ownership, growth opportunities, leverage, and financial distress simultaneously or together has a significant influence on conservatism. It is because the $\mathrm{F}$ test shows an $\mathrm{F}$ statistic probability value of $0.000000<\alpha(0.05)$, so $\mathrm{H}_{5}$ is accepted.

Through table 2 it can be seen that the adjusted R-squared value of 0.827766 or $82.77 \%$, so that managerial ownership, growth opportunities, leverage, and financial distress $82.77 \%$ affect the accounting conservatism, while the remaining $17.23 \%$ is explained by other independent variables not included in this study.

\section{CONCLUSION}

This study aims to analyze the effect of managerial ownership, growth opportunities, leverage, and financial distress on accounting conservatism in manufacturing companies, especially in the Miscellaneous Industry and Consumer Goods Industry sectors listed on the Indonesia Stock Exchange (IDX) with a research period from 2015 to 2017.

Based on the results of data processing on 21 sample companies it can be concluded that partially managerial ownership has no effect on the principle of accounting conservatism. Likewise, growth opportunities do not affect the principle of accounting conservatism. 
On the other hand, the leverage variable partially has a significant positive effect on accounting conservatism. Likewise with Financial distress has a significant positive effect on accounting conservatism. Meanwhile, the managerial ownership structure, growth opportunities, leverage, and financial distress simultaneously have a significant influence on accounting conservatism.

From these conclusions, it is recommended for further research to extend the study period so that the results obtained are more accurate. In addition, it is better to add other variables that might affect accounting conservatism because there are still 17.23 percent other factors besides the variables that have been examined in this study, such as cash flow operations, public ownership and inflation rates.

\section{REFERENCES}

1. Brigham \& Daves. 2011. Intermediate Financial Management. South Western: Ninth Edition.

2. Christiawan \& Tarigan. 2007. Kepemilikan Manajerial: Kebijakan Hutang, Kinerja and Nilai Perusahaan. Jurnal Akuntansi \& Keuangan, vol.9(1).

3. Dewi \& Suryanawa. 2014. Pengaruh Struktur Kepemilikan Manajerial, Leverage, and Financial Distress terhadap Konservatisme Akuntansi. E-jurnal Akuntansi, vol.7(1). Universitas Udayana.

4. Fachrudin, Khaira. 2008. Kesulitan Keuangan Perusahaan and Personal. Medan: USU Press.

5. Fatmariani. 2013. Pengaruh Struktur Kepemilikan, Debt Convenant and Growth Opportunities terhadap Konservatisme Akuntansi pada Perusahaan Manufaktur yang terdaftar di Bursa Efek Indonesia. Jurnal Akuntansi, vol.1(1). Universitas Negeri Padang.

6. Fatmasari, R. 2011. The Relation between Growth Opportunity, Leverage Policy and Function of Covenant to Control the Agency Conflict between Shareholders and Debtholders. Bulletin of Monetary, Economics and Banking, vol.13(3).

7. Harahap, Sofyan. 2018. Analisis Kritis atas Laporan Keuangan. Cetakan ke-14. Jakarta: Rajawali Pers.

8. Nasir, dkk. 2014. Pengaruh Struktur Kepemilikan Manajerial, Risiko Litigasi, Likuiditas and Political Cost terhadap Konservatisme Akuntansi. Jurnal Ekonomi, vol.22(2).

9. Noviantari \& Ratnadi. 2015. Pengaruh Financial Distress, Ukuran Perusahaan, and Leverage pada Konservatisme Akuntansi. E-Jurnal Akuntansi, vol.11(3). Universitas Udayana.

10. Platt, H. \& Platt, M. 2002. Predicting Corporate Financial Distress: Reflections on ChoiceBased Sample Bias. Journal of Economics and Finance, vol.26(2).

11. Quljanah dkk. 2017. Pengaruh Growth Opportunities and Leverage terhadap Konservatisme Akuntansi. Forum Ilmiah Pendidikan Akuntansi, vol.5(1). Universitas PGRI Madiun.

12. Ramadhani \& Lukviarman. 2009. Perbandingan Analisis Kebangkrutan Menggunakan Model Altman Pertama, Altman Revisi and Altman Modifikasi dengan Ukuran and Umur Perusahaan sebagai Variabel Penjelas. Jurnal Siasat Bisnis, vol.13(1).

13. Ramadona dkk. 2016. Pengaruh Struktur Kepemilikan Manajemen, Struktur Kepemilikan Institusional, Ukuran Perusahaan and Leverage terhadap Konservatisme Akuntansi. JOM, vol.3(1). Universitas Riau.

14. Risdiyani \& Kusmuriyanto. 2015. Analisis Faktor-faktor yang Mempengaruhi Penerapan Konservatisme Akuntansi. Accounting Analysis Journal, vol.4(3). Universitas Negeri Semarang.

15. Saputra dkk. 2016. Pengaruh Struktur Kepemilikan Manajerial, Kontrak Utang, Tingkat Kesulitan Keuangan Perusahaan, Peluang Pertumbuhan, Risiko Litigasi and Leverage terhadap Konservatisme Akuntansi. JOM, vol.3(1). Universitas Riau.

16. Sari dkk. 2014. Pengaruh Struktur Kepemilikan Institutional, Struktur Kepemilikan Manajerial, Struktur Kepemilikan Publik, Debt Covenant and Growth Opportunities terhadap Konservatisme Akuntansi. JOM, vol.1(2). Universitas Riau. 
17. Seftiani \& Handayani. 2011. Faktor-faktor yang Mempengaruhi Struktur Modal pada Perusahaan Publik Sektor Manufaktur. Jurnal Bisnis and Akuntansi, vol.13(1).

18. Septian \& Anna. 2014. Pengaruh Kepemilikan Manajerial, Ukuran Perusahaan, Debt Covenant and Growth Opportunities terhadap Konservatisme Akuntansi. eProceeding of Management, vol.1(3). Telkom University.

19. Sinambela \& Almilia. 2018. Faktor-faktor yang Mempengaruhi Konservatisme Akuntansi. Jurnal Ekonomi and Bisnis, vol.21(2). Universitas Kristen Satya Wacana.

20. Soesetio. 2008. Kepemilikan Manajerial and Institusional, Kebijakan Dividen, Ukuran Perusahaan, Struktur Aktiva and Profitabilitas terhadap Kebijakan Hutang. Jurnal Keuangan and Perbankan, vol.12(3). Universitas Negeri Malang.

21. Sudana, I Made. 2011. Manajemen Keuangan Perusahaan. Jakarta: Erlangga.

22. Sulastri \& Anna. 2018. Pengaruh Financial Distress and Leverage terhadap Konservatisme Akuntansi. Akuisisi, vol. 14(1).

23. Susanto \& Ramadhani. 2016. Faktor- faktor yang Mempengaruhi Konservatisme Akuntansi. Jurnal Bisnis and Ekonomi, vol.23(2).

24. Syafi'i, I. 2011. Managerial Ownership, Free Cash Flow and Growth Opportunity terhadap Kebijakan Utang. Media Mahardika, vol. 10(1).

25. Wahyuni \& Muchlis. 2016. Implikasi Konservatisme Akuntansi terhadap Sisa Hasil Usaha Koperasi Simpan Pinjam Melalui Prinsip Muqabalah pada KSP Nasional Kabupaten Pinrang. Jurnal Ilmiah Akuntansi Peradaban, vol.2(1).

26. Wulandari dkk. 2014. Pengaruh Struktur Kepemilikan Manajerial, Debt Covenant and Growth Opportunities terhadap Konservatisme Akuntansi. JOM, vol.1(2). Universitas Riau.

27. Zuhriyah. 2017. Konvergensi IFRS, Leverage, Financial Distress, Litigation dalam Kaitannya dengan Konservatisme Akuntansi. Equity, vol. 3(1). Universitas Bhayangkara Surabaya. 